Milan Tomić ${ }^{1}$

Sandra Rover ${ }^{2}$

Bojan Pejović ${ }^{3}$

University of Montenegro, Faculty of Economics

Nina Uremović 4

Pan-European University ,,Apeiron ' Banja Luka
P. 49-62

SCIENTIFIC REVIEW ARTICLE

DOI: $10.5937 / \mathrm{ESD} 2002050 \mathrm{~T}$

Received: March, 19. 2020.

Accepted: Jun, 05. 2020.

\title{
FUNCTIONAL LINKS BETWEEN RURAL AND URBAN AREAS IN THE TERRITORY OF THE CITY OF BANJA LUKA AND THE PERSPECTIVE OF THEIR DEVELOPMENT
}

\begin{abstract}
Different types of interactions between rural and urban areas have the effect of improving economic, social, cultural and political dimensions in both areas, separating these two areas by their type of activity. Rural and urban types of regions have different resources and means that can be used in a complementary way. In rural-urban interaction there is a possibility of occurrence of conflict of interest of these two areas. This kind of conflict should be overcome when applying the partnership approach between rural and urban areas. The types of rural areas, depending on the proximity of the urban center and the functions of these areas, are divided into suburban, agricultural and remote type areas. By determining the functions of each type of area, the type and intensity of the interactions of rural areas with the urban center are presented. Rural entrepreneurs are able to bridge rural-urban differences, possessing certain market knowledge and descriptions of the characteristics of urban environments, while benefiting from their position. Rural entrepreneurs' interaction with the urban environment can contribute to sustainable economic relations between citizens in urban and rural areas. This paper presents the results of research related to determining the functions of certain areas, their strengths, unused and utilized resources, the frequency of interaction with the urban environment and the perspectives of suburban, agricultural and remote type areas in the context of interaction with the urban environment.
\end{abstract}

Key words: economics of development, functional relations, trade: general, urban, rural and regional economy.

JEL classification: F 10, P25

\footnotetext{
${ }^{1}$ milantm93@gmail.com, ORCID-ID orcid.org/0000-0002-4589-2175

2 sandra.rover456@gmail.com, ORCID-ID orcid.org/0000-0002-8760-6421

${ }^{3}$ bojanpejo-vic@hotmail.com, ORCID-ID orcid.org/0000-0001-9220-9327

${ }^{4}$ nina.d.uremovic@apeiron-edu.eu, ORCID-ID orcid.org/0000-0001-5445-2262
} 


\title{
ФУНКЦИОНАЛНЕ ВЕЗЕ ИЗМЕЪУ РУРАЛНИХ И УРБАНИХ ПОДРУЧЈА НА ТЕРИТОРИЈИ ГРАДА БАЫА ЛУКЕ И ПЕРСПЕКТИВА ЊИХОВОГ РАЗВОЈА
}

\begin{abstract}
Апстракт
Различитим врстама интеракције између руралних и урбаних подручја долази до побољшана економских, друштвених, културних и политичких димензија у оба подручја, раздвајајући ова два подручја по врсти юихових активности. Рурални и урбани типови региона имају другачија средства и ресурсе који се могу користити на комплементаран начин. Приликом руралноурбане интеракиије постоји могућност појављивањ а сукоба интереса ова два подручја. Овакав вид сукоба би требао да се превазиђе применом приступа партнерства између руралних и урбаних подручја. Врсте руралних подручја зависно од близине урбаног ичентра и функција тих подручја, деле се на приградски, пољопривредни и забачени тип подручја. Одређивањем функција сваког типа подручја, долази се до приказивања врсте и интезитета интеркаиија руралних подручја са урбаним центром. Рурални предузетници су у стану да премосте рурално-урбане разлике, поседујући одређена знања о тржишту и описе карактеристика урбаних средина, истовремено профитирајући од свога положаја. Рурални предузетници интеракциом са урбаном средином могу допринети одрживим економским односима између грађана у урбаним и руралним срединама. Овај рад приказује резултате истраживања везане за одређивање функиија одређених подручја, њихових снага, неискориштених и искориштених ресурса, учесталости интеракције са урбаном средином и перспективи приградског, пољопривредног и забаченог типа подручја у контексту интеракције са урбаном средином.
\end{abstract}

Кључне речи: економија развоја, функционални односи, трговина: општа, урбана, рурална и регионална економија.

\section{Introduction}

Rural-urban linkages play a crucial role in the generation of income, employment and wealth. Yet, for various reasons the importance of such linkages is not recognized and thus ignored in national economic and trade policies (Sule Akkoyunlu, 2015). By analyzing the rural areas in the territory of Banja Luka, we get an overall picture of the interaction of rural and urban space. When defining the economic, social, cultural and political aspects of rural areas that are changing in relation to the types of areas, a picture of spatial and sectoral flows that take place between rural and urban areas is presented. The rural-urban linkages may be defined as the two way movement of people, goods, capital, technologies and social transaction which is functional and structural. Rural-urban linkages are both a cause and a consequence of socioeconomic and cultural development (Raisul Bari, 2014). According to Ruddle (1979), a balanced spatial system can be achieved in most developing countries by stimulating increased production, employment and demand in rural areas and by extending to smaller settlements the 
services and facilities that will encourage increased productivity and the consolidation of rural population into larger economic centers.

Functional links between rural and urban areas can be defined as economic, social, cultural and political relations between the urban environment (center) with all its economic, social, cultural and political aspects and with all the aspects that are in rural areas. Rural-urban links can also be defined as spatial and sectoral flows that take place between rural-urban areas. Spatial flows include flows of people, goods, money, technology, information, knowledge and even waste. On the other hand, sectoral flows are flows of agrarian products that come from rural to urban areas, diversely goods produced in urban centers circulate to rural areas. The articulation of rural-urban relations is expressed in all forms of population migration, daily, weekly, monthly as well as in the production of goods, consumption, financial and investment ties, exchange of money, goods, social relations between relatives and friends in rural and functional environments. According to Evans (1990), rural-urban linkages may be thought of as trade, exchange, and the flow of the ressources between one spatial component of the national economic system and another, where these resources include goods, services, money, remittances, savings, investments, public revenues and expenditures, labor, migrants and information.

The main household income from rural areas, depending on the type of area, is based on work in agriculture on own holdings, work in non-agricultural activities on own holding / household, work with employers in non-agricultural holdings, work in agriculture at other farm / company, work in own company in non-agricultural sector and income from non-profitable income (rent, dividend, donation).

When proving and analyzing the key functions of rural areas, depending on the type of area (suburban, agricultural and remote) and their economic, social, cultural and political aspects, their interaction with the urban center is shown. For the suburban (industrial) type of area, the populated place of Ramici was analyzed. The local community of Motike and the local community Ljubacevo were analyzed for agricultural and remote type of area.

\section{Literature review and theoretical framework}

Arguments associating rural-urban linkages have continuously received attention in development policy as an important process in both socio-ecological and economic sustainability process both in rural and urban areas (Farai Kapfudzaruwa and associates, 2018; Tacoli and Satterthwaite, 2015; Lazaro and associates, 2017).

Rural-urban linkages can be defined as the structural social, economic, cultural, and political relationships maintained between individuals and groups in the urban environment and those in rural areas (Lesetedi, 2003; Lindile L. Ndabeni, 2016). Ruralurban linkages can also be interdependence as spatial and sectoral flows that occur between rural and urban areas (Tacoli, 1998; Bah et al., 2003; Von Braun, 2007).

Traditionally, the economic and territorial development of rural and urban areas have been considered separate topics in both research and policy, where this statement has been reinforced by the sense that differences in economic, cultural and spatial circumstances lead to differences in economic, cultural and social interests. However, urban and rural areas are increasingly integrated both physically and functionally, and 
because of their distinct and complementary endowments, closer integration can bring benefits to both (OECD Rural Policy Reviews, 2013).

Driven by technological progress, improvements in infrastructure, and liberalization and the creation of markets, globalization has meant rapid rural transformation across the developing world (Joachim von Braun, 2007). Perspective on rural-urban linkages is particularly important in the context of sustainable economic development. There is increasing evidence that with the growing integration of the global economy, trade liberalization, increasing importance of a knowledge based economy, etc. large urban agglomerations are disproportionately benefitting from these developments (Akgün A. A, 2008; Mayer and associates, 2016). According to Czischke (2015), for sustainable urban development there are 3 important "topics", which one of them is rural-urban linkage. Together, these "topics", aim to contribute to the overarching goals of more sustainable development, where rural-urban linkage need to be strengthened in the future.

Economically, there is a large division between cities and the rest of $\mathrm{BiH}$, with official statistics showing that Sarajevo, Banja Luka, and the other four big cities have almost 40 percent lower unemployment, 25 percent higher salaries and more than twice the GDP per capita in relation to the rest of the earth, which all cause significant migration of people from rural areas to cities (Goran Živkov, 2013).

The Urban-rural typology classifies the NUTS-3 (Nomenclature of Territorial Units for Statistics) regions of the European Union (EU) into three different categories: predominantly urban, intermediate and predominantly rural. Predominantly urban regions have less than $20 \%$ rural population, intermediate regions between $20 \%$ and $50 \%$ and predominantly rural regions more than $50 \%$ (Updated urban-rural typology, 2013).

Cities are seen as motors of smart, sustainable and inclusive development and attractive places to live, work, visit and invest in. Urban-rural interdependence should be recognized through integrated governance and planning based on partnership (Mendez, 2011, Andrew Copus 2015).

Rural incomes are decreasingly based only on agriculture. This is positive in that it allows smallholder families to invest in agricultural production, and be less dependent on the insecurity inherent in farming. In many cases income diversification involves migration to urban centres; but in the most positive cases, income diversification goes hand in hand with the diversification of the local economic base, where processing of agricultural retains added value and provides non-farm jobs (Cecilia Tacoli, 2013).

\section{Objective and methods of work}

The aim of this research is to present functional links between rural and urban areas, which include sectoral and spatial flows between rural and urban areas in the territory of the city of Banja Luka and the perspective of their development. In order to analyze the current state as the starting point in each research, the different functions of rural areas will be presented depending on the type of area and their changes, starting from suburban areas dominated by the secondary and tertiary sector, agricultural areas where the primary sector is most concentrated to the remote areas. By showing the perspective of improving rural-urban connections, it would be reflected in urban-rural partnerships based on the 
potential of these areas. Urban and rural areas have different descriptions of functions that can complement one another and create a better socioeconomic performance.

Starting with the object and purpose of the research, standard statistical methods that are common to this type of research are used. The research used a statistical method where the results are presented by graphical analysis, the descriptive method, based on which the existing available resources and the way of their use are described, the method of proofing, the method of analysis and synthesis, the comparative method, induction, deduction and survey. During the survey, the survey method used was realized using a structured questionnaire and included questions about demographic data on the household, sources of income of the household, types of connections with the urban area and rural development. The survey included 45 households in the rural areas of Banja Luka. For the purposes of this paper, data from the Statistical Office of the Republic of Srpska were used, data from municipal authorities and ministries, chamber system, business entities, etc. The used literature and data sources are statistical anniversaries, strategies, results of scientific papers and other available domestic and foreign literary sources.

\section{Functional links between rural and urban areas in Europe}

In all EU Member States, local and regional authorities have built rural-city partnerships to better exploit the potential of such regions. The European Union's emphasis on defining rural and urban areas is placed in areas where it is more difficult to define the distinction between rural and urban areas.

Eurostat has established an urban-rural typology, the Nomenclature of the Territorial Units for Statistics (NUTS1, NUTS2 and NUTS3). 51.3\% of the EU's land area is predominantly rural and inhabited with $22.3 \%$ of the total EU population 502 million). Estonia, Ireland, Greece, Portugal and Finland are predominantly rural areas (80\% of the territory).

Promoting partnerships can be seen in Italy, where the metropolitan area of Milan has partnership relations with the Alpine areas. The best example of partnerships between urban and rural areas can be seen in Amsterdam.

The project for the development of functional connections in Amsterdam started in 2006 and is managed by the Municipality of Amsterdam. The objectives of this project were to support the production of healthy food and nutrition, sustainable local food chains that interacted with rural areas. The strategy of this project was based on the combination, linking and increasing of the current initiative in the field of sustainable agriculture and healthy food. In Amsterdam in 2010, new calls for interested parties in the food chain were created and involved in the development of functional links between rural and urban areas. The increase in the sales of products produced in rural areas from $3.4 \%$ in the beginning, 2007 to $7 \%$ by the end of 2007 was achieved on the entire territory of the city of Amsterdam. In 2010, there was an increase in sales of food produced in rural areas in the City of Amsterdam in canteens by $60 \%$. 


\section{Results of Research}

According to the NUTS nomenclature, Banja Luka belongs to NUTS 3 in the Intermediate regions, where the percentage of rural population in relation to the total population is $25 \%$. The total area of rural areas is $1055.68 \mathrm{~km} 2$, which is $85.18 \%$ of the territory of the city of Banja Luka. According to the Statistics Institute, the percentage share of the number of inhabitants of the rural area in the number of inhabitants of Banja Luka in 2013 amounted to 24.9\%. The coverage of the rural area of Banja Luka consists of 40 complete settlements and two parts of the settlement. The number of registered persons (households) engaged in agriculture in rural areas of Banja Luka in 2015 amounted to 8,018 . The share of households engaged in agricultural activity and selling products on the market is $6,70 \%$.

According to the OECD methodology, three types of rural areas, suburban type, agricultural type and remote type are identified. The suburban type of the area is dominated by the secondary and tertiary sector, while the income from agriculture is very significant. In the agricultural type, income is mostly based on the primary sector, while there is a significant increase in nonagricultural activities such as tourism. Remote type of area is characterized by low income in agriculture with certain service activities is predominantly represented.

Ramici is a populated place on the territory of the town of Banja Luka, which is a part of to the local community of Dragocaj. Thanks to its close proximity to the city and good infrastructure connections (the main road M4 and the railway that connects the cities of Banja Luka and Prijedor), a part of the inhabited village of Ramici has been turned into the business zone "Ramići-Banja Luka". According to the 2013 population census, the village of Ramici has 1,757 inhabitants. A large number of business entities and proximity to the city tell us that Ramici is a suburban settlement or an industrial type of settlement. Although a part of Ramici has been turned into an industrial, business zone of Ramici, despite a large number of business entities, agriculture in this settlement is not negligible. In addition to income from the tertiary and secondary sectors, most of the population is engaged in agriculture, which improves the income of their household. There are 15 companies in the business zone of Ramici: "Tri best", "Sim Impeh", "Sepl", "Messer BH gas", "Modul”, "Noraplast", "Tehnomerkur", "Elas Metalekspert", “Tenzo", "Madaco", “21 May", "ET Mah”, "Jaćimovic”, "MK Majkić” and "Rolofeks". Most businesses in Ramici fall into the secondary or tertiary sector. The total number of business entities in Ramici is 40 . The number of business entities by activity is mostly from trade with 12 entities, industry and household activities with 7 and accommodation activities with 5 entities. Household income according to the research in the inhabited village of Ramici is based on the highest work with the employer in the non-agricultural sector outside the populated village of Ramici with $40 \%$, while the second is the most represented group in agriculture in their own households of $27 \%$. The most common types of agricultural activities in the household in 2018 are the production and processing of agricultural products, and the participation of organic food production is high. According to the survey, the majority of $80 \%$ of inhabitants daily visit the city of Banja Luka.

The Motike community is located north-west of the city center. According to Motiki typology, they represent the agricultural type of area, where most households are engaged in agricultural production. According to the 2013 population census, the 
local community of Motike has a population of 2,515 inhabitants. The total number of registered economic entities is 24 , where the largest number of companies are from the sphere of professional and technical activities. The survey shows that the main source of income for households is based on work with the employer in the non-agricultural sector, with $37 \%$, where most of the population works in the urban part of Banja Luka. Most of the respondents, apart from work in the non-agricultural sector, also receive income from agricultural production, which represents secondary income of these households and is represented by $32 \%$, where most of the respondents are engaged in the cultivation of fruits, vegetables and stock farming. During the survey the respondents stated that they have daily visit to the city of Banja Luka with $67 \%$. Residents traveling daily for the city of Banja Luka have permanent employment in the urban part of the city or attending secondary schools and colleges.

The local community Ljubacevo is located south-east of the city center of Banja Luka. According to typology Ljubacevo represents a remote type of settlement. According to the 2013 population census, the local community Ljubacevo has a population of 463 inhabitants. On the territory of the local community Ljubacevo there is the ethno village "Ljubačke doline" which provide rural tourism services. The number of registered business entities in the territory of Ljubacevo is 6, and these are 2 economic entities from the sphere of secondary industry (wood processing, stone processing / quarrying). According to the survey, the main sources of income for households by 2018 are agricultural work on the holding $27 \%$ and work with the employer in the nonagricultural sector with $39 \%$. According to the research, most respondents daily visit the city of Banja Luka with the rate of $60 \%$, while the smallest percentage of respondents visit the urban part of the city on a monthly basis with the rate of $13 \%$.

\section{Discussion of research results}

The main sources of income for households in all three areas are income from work with the employer in the non-agricultural sector. The agricultural area has the largest share of income from agricultural work on own holdings from all surveyed areas with $32 \%$. According to the types of activity on the holding, from which revenues are realized in all three areas, they have a dominant role in the production of agricultural products, organic food production and the production of processed products. In addition to the mentioned activities on the holding, the remote area in relation to the other two areas also has activities from the sphere of traditional crafts and activities of providing rural tourism services. The remote area is the only area of study that has preserved the majority of traditional crafts, such as embroidery, blacksmithing and others.

Unused resources in the suburban area are agricultural land, facilities and manpower, also represent unused resources in households. The agricultural area in relation to the suburban area along the agricultural land, from unused resources has water and a smaller share of forests. The main unused resources in households in the agricultural area are agricultural land and labor. Unlike the other two areas, the remote area has the largest percentage of unused forest resources, stone and a smaller percentage of agricultural land. The unused factors or the reasons for the higher degree of utilization of resource resources in the farm in all three examined areas are primarily the lack of 
finances, the possibility of placing goods and the quality of the land when dealing with agricultural production.

Visits of respondents to the urban part of Banja Luka from all three settlements were frequent, and are mostly based on daily visits. Starting from the suburban area whose daily visits are the most frequent ( $80 \%$ of respondents), the agricultural area $(67 \%)$ to the remote area whose daily visits are the least $(60 \%)$ and monthly visits the most. The frequency of the visit of the respondents is mainly reflected in employment in the urban part of the city, and in the vicinity of the city, so that the largest percentage of respondents from the suburban area work in the urban part of the city. From these movements, we can notice that the spatial flows of people from the suburban area are the most common of all three settlements. Private cars are the main means of transport in all three settlements. The main reasons for visiting the city of respondents from the suburban area, the agricultural area and the remote area are reflected in a job in the city, the purchase of personal consumption goods and visits to relatives and friends. Visits of respondents from the suburban area to the urban part of the city are dependent by visiting payment institutions, while respondents from the agricultural area visit the urban part due to the sale of agricultural products. The frequency of visits of relatives and friends from Banja Luka to households is most noticeable in the suburbs and the agricultural area, and are based mostly on the weekly level, while the visits of relatives and friends of the remote area are somewhat less common and are based on the monthly level. Procurement of goods, consumption and use of services and information are the main reasons for the visits of tourists and customers to households and examined areas.

The advantages of living in the suburban area, the agricultural area and the outlying area are as follows:

- In lower life costs,

- The ability to deal with agricultural production and a cleaner environment,

- Proximitythese of this areas with the urban part of the city,

- Good infrastructure connectivity.

Factors that attract respondents from the suburban, agricultural and remote areas to move to the urban part of the city are the dominant opportunities for better employment and in a smaller proportion for better access to infrastructure content and better education. The suburban area holds the largest number of public services, where the remote area has the smallest number of services.

- The development perspective of the suburban area is reflected in a good position (near the city), a very good entrepreneurial environment and human resources.

- The perspective of development of the agricultural area is somewhat different from the suburban area and it is reflected in the possibilities of dealing with agricultural production, possibilities of exploitation of groundwater in terms of improving agricultural production in irrigation and labor.

- The remote area has the largest number of natural resources such as stone and forest, and their perspective is based on the secondary industry (stone and wood processing). In addition to the secondary industry, the remote area has a good perspective for the development of rural tourism, where this local community has the only ethnic village in the entire region. 
The suburban area has the best entrepreneurial environment and the most business subjects from the research areas. Suburban area, with business zone, owns 40 registered business entities, which is far greater than the agricultural area and the remote area (Table 1).

Table 1. SWOT (strengths, weaknesses, opportunities, and threats) analysis of suburban areas

\begin{tabular}{|c|c|}
\hline Strengths & Weaknesses \\
\hline $\begin{array}{l}\text { - Proximity to urban market } \\
\text {-Good demographic and educational structure } \\
\text {-Access to the main road M4 } \\
\text {-Access to the railroad } \\
\text {-Well developed infrastructure } \\
\text {-Education for entrepreneurship } \\
\text {-Good entrepreneurial environment } \\
\text {-Strong spatial flows }\end{array}$ & $\begin{array}{l}\text {-The lack of public services (payment } \\
\text { institutions, sports hall) } \\
\text {-Notness of manifestations } \\
\text {-Problem of unemployment } \\
\text {-Unused resources } \\
\text {-Demographic aging } \\
\text {-The number of household members }\end{array}$ \\
\hline $\begin{array}{l}\text { Opportunities } \\
\end{array}$ & $\begin{array}{c}\text { Threats } \\
\end{array}$ \\
\hline $\begin{array}{l}\text {-The ability of startups for young people to } \\
\text { start their own business } \\
\text {-The possibility of better utilization of the land } \\
\text { for agricultural purposes } \\
\text {-Using the labor force, good education of the } \\
\text { population in order to develop the secondary } \\
\text { and tertiary sector } \\
\text {-Using the funds for the development of SMEs } \\
\text {-Easy access to the urban and regional market } \\
\text {-Development of entrepreneurship and } \\
\text { entrepreneurial zones } \\
\text {-New investments by domestic and foreign } \\
\text { investors }\end{array}$ & $\begin{array}{l}\text {-As soon as urbanization spreads, there is an } \\
\text { increase in cost of living } \\
\text { - Reducing agricultural land } \\
\text {-The possibility of polluting the environment } \\
\text {-Migration of the population towards the } \\
\text { urban part }\end{array}$ \\
\hline
\end{tabular}

Source: Authors

SWOT analysis of the suburban type of the area primarily emphasizes the proximity of the market and the entrepreneurial environment as the strength of this area, where the spatial flows are very pronounced (Table 2). Good infrastructure connectivity enables the rapid development of the entrepreneurial environment, where local people use low taxes and close proximity to the market. The disadvantages of this area are reflected in the lack of certain institutions (payment institutions) and the lack of the cultural events. The chances of development of this environment are reflected in the possibility of developing entrepreneurship and entrepreneurial zone, new investments and opportunities for access to urban and regional markets. 
Table 2. SWOT analysis of agricultural areas

\begin{tabular}{|c|c|}
\hline Strengths & Weaknesses \\
\hline $\begin{array}{l}\text { - The proximity of the city and the market } \\
\text { - Good demographic and educational structure } \\
\text { - Well-developed infrastructure } \\
\text { - Any sectoral flows } \\
\text { - Providing agriculture } \\
\text {-Hydro potential for irrigation purposes } \\
\text { - Cheaper life and cleaner environment }\end{array}$ & $\begin{array}{l}\text {-Extensive agriculture } \\
\text { - Older varieties in fruit growing } \\
\text { - Lack of public services (payment } \\
\text { transactions, kindergartens for children, } \\
\text { police station, veterinary station) } \\
\text {-Low sources of income based on urban areas } \\
\text { - The lack of holding events }\end{array}$ \\
\hline $\begin{array}{c}\text { Opportunities } \\
\end{array}$ & Threats \\
\hline $\begin{array}{l}\text {-Regulation of agricultural products on the city } \\
\text { market } \\
\text {-The possibility of better exploitation of } \\
\text { underground and above ground water } \\
\text {-The ability to deal with intensive agriculture } \\
\text {-Using the proximity of the market } \\
\text {-Using human resources in the development } \\
\text { of agricultural production and entrepreneurship } \\
\text { - Better exploitation of incentives for the } \\
\text { development of agricultural activities }\end{array}$ & $\begin{array}{l}\text { - Weather conditions } \\
\text {-Migration of the population towards the } \\
\text { urban part } \\
\text { - With the expansion of urbanization, there is } \\
\text { an increase in the cost of living } \\
\text {-The possibility of polluting the environment }\end{array}$ \\
\hline
\end{tabular}

Source: Author.

The strengths of the agricultural area are reflected in the vicinity of the city, welldeveloped infrastructure, cheaper life and opportunities for agriculture (strong sectoral flows). The concept of the agricultural area is reflected in the possibility of dealing with intensive agriculture, exploitation of hydro potentials for irrigation and better exploitation of the proximity of the market. Weaknesses are reflected in extensible agriculture, the lack of revenue sources and the lack of specific institutions (payment transactions, childcare facilities, police stations, veterinary stations) and the lack of event holding. The vicinity of the city and future urbanization can lead to more expensive life in the agricultural area. Weather disasters can affect agricultural production.

SWOT analysis of the remote type of the area emphasizes the strengths of natural resources (stone and forest), cheaper life and healthier environment, and the possibility of rural tourism (Table 3). Chances are reflected in the development of rural tourism, the increase in the volume of traditional crafts and the development of the industry for the processing of raw materials of stone and forest. Population aging, receding of population and lack of institutions represent the main weaknesses of this remote area. Constant decline in population can lead to social isolation of this area, where migration towards the city would increase in the future decline of population. According to the Development Strategy of the City of Banja Luka in the period 2018-2027, the emphasis of further development of the city would be on the development of rural tourism based on sustainable development. Where the tendency of modern tourism is based on clean, ecologically unpolluted environments. This sight of tourism also means the development of underdeveloped rural parts of the city, increased employment and a source of additional income for the local population. 
Table 3. SWOT analysis of remote areas

\begin{tabular}{|c|c|}
\hline Strengths & Weaknesses \\
\hline $\begin{array}{l}\text { - Rich in resources (forest, stone) } \\
\text { - Preserved natural wealth } \\
\text { - Traditional crafts and products preserved -The } \\
\text { possibility of dealing with rural tourism - Good } \\
\text { education structure } \\
\text { - Well developed infrastructure } \\
\text {-Cheaper life and cleaner environment } \\
\text {-The ability to deal with agricultural production }\end{array}$ & $\begin{array}{l}\text {-Demographic aging } \\
\text { - The lack of a large number of institutions } \\
\text { (payment institution, police station, } \\
\text { elementary school from } 6 \text { to } 9 \text { classes, self- } \\
\text { service, agricultural pharmacy) } \\
\text { - The lack of holding cultural events } \\
\text {-Reducing the number of inhabitants - Bad } \\
\text { soil quality } \\
\text {-Absence of income diversification }\end{array}$ \\
\hline Opportunities & $\begin{array}{c}\text { Threats } \\
\end{array}$ \\
\hline $\begin{array}{l}\text {-Obtaining rural tourism supply } \\
\text {-Branding traditional products } \\
\text { - Better use of resources (forest, stone) } \\
\text {-Development of secondary industry (stone } \\
\text { processing, forests) } \\
\text {-The potential for organic farming }\end{array}$ & $\begin{array}{l}\text { - Downturn in the population } \\
\text {-Weather disasters } \\
\text {-Migration of the population } \\
\text {-The lack of a source in income }\end{array}$ \\
\hline
\end{tabular}

Source: Author.

\section{Perspective of the development of functional links in Banja Luka}

The perspective of the development of functional links between rural and urban areas in Banja Luka could be based on a rural-urban partnership. The concept of ruralurban partnership would be based on the potential of these areas. Urban and rural areas have different descriptions of functions that can complement one another and create better socio-economic performance. When developing functional links between rural and urban areas in Banja Luka, the principle of this partnership could be seen in the example of a rural-urban partnership implemented in Amsterdam. The rural-urban partnership project from 2006 to 2010 in Amsterdam was rated as the best example of good practice in the world and was based on combining, linking and increasing incentives in the field of sustainable agriculture and healthy food.

The principle of the development of functional connections between rural and urban areas in the territory of Banja Luka would be managed by the municipality of Banja Luka and local authorities. The aim of the project would be to support the production of organic food as well as the nutrition of inhabitants of urban and rural areas, maintaining local food chains that would interact with rural areas. The strategy of this project would be based on the combination, linking and increasing of initiatives in the field of sustainable agriculture and healthy food. Guidelines that would complement sustainable agriculture and organic food production would be reflected in the promotion of nutrition in primary and secondary schools, healthcare institutions, the organization of catering facilities where locally produced food from rural areas of Banja Luka would be offered. The rural-urban partnership project would also be reflected in cooperation in the 
regional food chain and the sale of rural products in the urban environment, the re-use of organic waste, the sustainable transport of food and the use of logistics.

By holding seminars in rural areas, farms could be given guidance to farmers how to operate in this partnership, where local farmers would directly connect with the city market. Institutes for professional training, advisory services would cooperate with small and medium-sized entrepreneurs at the municipal level, supporting the development of functional connections and partnerships between rural and urban areas of Banja Luka. This type of partnership would directly influence the improvement of socio-economic relations between rural and urban areas and would contribute to enabling the development of rural areas, where the local population would have permanent income from agriculture.

\section{Conclusion}

All three types of research areas have well developed spatial and sectoral flows, while certain types of spatial and sectoral flows are dominant in a particular type of settlement. In the suburban-industrial type of area, the most important are the flows of currents, such as the flows of people, who mostly have employment in the city, the flows of manufactured goods from this area, and the like. Spatial flows such as the flow of people, goods, money, technologies are clearly present in the interaction of the suburban type of the area with the city of Banja Luka. Agricultural types of areas, in addition to less pronounced spatial flows than in industrial type of settlements, have very pronounced sectoral flows. The main description of the interaction of the agricultural type of the area with Banja Luka can be seen through sectoral flows, where most of the respondents who are engaged in agricultural production sell their products in the urban part of the city through short and long distribution channels, on stalls, markets etc. The diverted type of area possesses strongly dependent conditioned links, due to the lack of specific content, where the inhabitants of these landscapes are conditioned to go to the urban part of the city when visiting most of the content.

In all three types of areas, people's flows are clearly visible, where most of the population in these areas has permanent employment in the city. The good infrastructure connection of rural areas with the city of Banja Luka enables the rural population easy and quick access to the city. The perspective of the development of functional links between rural and urban areas in Banja Luka could be based on a rural-urban partnership. The principle of the development of functional links between rural and urban areas in the territory of the city of Banja Luka would be managed by the municipality of Banja Luka and local authorities.

\section{References}

Akgun, A. A. G., \& Baycan, T. (2008). Changing Trends in Rural Self-Employment in Europe and Turkey.

Akkoyunlu, S. (2015). The potential of rural-urban linkages for sustainable development and trade. International Journal of Sustainable Development \& World Policy, 4(2), 20. 
Bah, M., Cissé, S., Diyamett, B., Diallo, G., Lerise, F., Okali, D., ... \& Tacoli, C. (2003). Changing rural-urban linkages in Mali, Nigeria and Tanzania. Environment and Urbanization, 15(1), 13-24.

Bari, Raisul \& Munir, Prof. (2014). Spatial Analysis of Rural-Urban Linkages in Basti District (U.P.). IOSR Journal of Humanities and Social Science. 19. 127-133. 10.9790/0837-1944127133.

Copus, A. K., \& de Lima, P. (Eds.). (2014). Territorial cohesion in rural Europe: the relational turn in rural development. Routledge.

Czischke, D., \& Pascariu, S. (2015). New Concepts and Tools for Sustainable Urban Development in 2014-2020. URBACT Study synthesis report. European Union. European Regional Development Fund.

Development Strategy of the City of Banja Luka in the period 2018-2027.

Evans, H. E. (1990). Rural-urban linkages and structural transformation. World Bank, Sector Policy and Research, Infrastructure and Urban Development Department.

Goran Živkov (2013); Rural development in Bosnia and Herzegovina: Myth and reality

Kapfudzaruwa, F., Kudo, S., \& Hansen, M. (2018). Rural-urban Linkages and Sustainable Development. Rural-Urban Linkages and Sustainable Development in Africa, 1.

Lazaro, E., Agergaard, J., Larsen, M. N., Makindara, J., \& Birch-Thomsen, T. (2017). Rural Transformation and the Emergence of Urban Centres in Tanzania. IGN Report, October.

Lesetedi, G. N. (2003). Urban-rural linkages as an urban survival strategy among urban dwellers in Botswana: the case of Broadhurst residents. Journal of Political Ecology, 10(1), 37-46.

Mastilo, Z. (2013). Analiza stanja makroekonomskih agregata u Republici Srpskoj i Bosni i Hercegovini u funkciji održivog razvoja. Anali Ekonomskog fakulteta $u$ Subotici, (29), 133-148.

Mayer, H., Habersetzer, A., \& Meili, R. (2016). Rural-urban linkages and sustainable regional development: The role of entrepreneurs in linking peripheries and centers. Sustainability, 8(8), 745.

Mendez, C., Bachtler, J., \& Wishlade, F. (2011). Comparative study on the visions and options for cohesion policy after 2013.

Ndabeni, L. L. (2016). An analysis of rural-urban linkages and their implications for policies that sustain development in a space continuum. Cooperative Governance Traditional Affair, South Africa, www cogta. com.

Partnerships, R. U. (2013). OECD Rural Policy Reviews.

Ruddle, K., \& Rondinelli, D. A. (1979). Urban Functions in Rural Development: Integrating Spatial Systems for Equitable Growth. Journal of Economic Development, 4(1), 91-116.

Tacoli, C. (1998). Rural-urban interactions: a guide to the literature. Environment and urbanization, 10(1), 147-166. 
Tacoli, C., \& Satterthwaite, D. (2013). Gender and urban change.

Tacoli, C., McGranahan, G., \& Satterthwaite, D. (2015). Urbanisation, rural-urban migration and urban poverty. Human Settlements Group, International Institute for Environment and Development.

Von Braun, J. (2007, June). Rural-urban linkages for growth, employment, and poverty reduction. In Ethiopian Economic Association Fifth International Conference on the Ethiopian Economy (pp. 7-9). 